\title{
Making Sense of Learner Autonomy in Efl Classes. The Case of Basic English Skills Students at See University
}

\author{
Rufat Osmani \\ South East European University
}

\begin{abstract}
.
The concept of learner autonomy is currently dealt as a serious objective of many educational curriculums where students are mostly concerned with learning and here the student is competent of his/her own learning whereas the teacher has the role of a guide. Accordingly, in the learning process students are encouraged to have a very active role and are characterized with critical thinking and reflection and they also monitor and evaluate their own learning, make decisions and take independent actions.

There is a variety of exercises which can be used in EFL Classes for the purpose of "swapping" roles with the teacher where learners are given the chance to be involved in the selection of activities.

The objectives of this study are:

- To discover activities that evaluate the autonomous learning capacity of SEE University Basic English Skills students;

- To discover whether SEE University students are ready for autonomous learning or not;

- To discover threats that obstruct application of learner autonomy in EFL classes of SEE University students.

Data was collected in Basic English Skills classes, offered at the South East European University in Tetovo, Republic of Macedonia, during the academic year 2018-2019. A total number of 53 students, aged 18-25 participated in the study. The qualitative and quantitative methods were used in order to analyze the data collected during the research.
\end{abstract}

Keywords: learner autonomy, EFL, exercises, learner.

\section{Introduction}

Higher education policies are more and more enforced to get the shape of the global economy trends. These policies involve creation of autonomous students who are able to cope with and to successfully deal with different situations and in different circumstances. This brought to light the need for students to be active when learning a foreign language. Conversely to the traditional method where the teacher gives the information, in this case, the teacher has the role of the facilitator and students take responsibility of their own learning. 
With this intention, a variety of activities could be used in order to promote autonomous learning in EFL classes. Additionally, instructors also need to know students' needs, learning styles, background knowledge, culture, etc.

The roots of learner autonomy approach in education can be found in the 1980s when Henri Holec invented the term "learner autonomy". Due to the fact that he is considered as the "father" of learner autonomy Holec (1981:3) in his book Autonomy and Language Learning defines autonomy as the "ability to take charge of one's own learning". This ability "is not inborn but must be acquired either by 'natural' means or (as most often happens) by formal learning, i.e. in a systematic, deliberate way". He points out that "To take charge of one's learning is to have [...] the responsibility for all the decisions concerning all aspects of this learning $[\ldots]$ ".

This study explores some useful activities that lead students to be more productive and also foster learner autonomy.

\subsection{Literature Review}

In the literature on learner autonomy in EFL it is held in common to base most of the definitions on Henri Holec's description as he first introduced this concept. Driven by this, Zhuang, (2010, p. 593) states that "the teacher is not a transmitter of knowledge anymore but an instructor or supervisor in the learning process." Here the role of the student is critical as he/ she himself/ herself defines his/ her route to learning the target language. By the same token, Dickinson (1978:11), claims that "Autonomy is a situation in which the learner is totally responsible for all the decisions concerned with his [or her] learning and the implementation of those decisions." Even more, learner autonomy is based on the idea that if students are involved in decision making processes regarding their own language competence, "they are likely to be more enthusiastic about learning" (Littlejohn, 1985, p. 258).

With the emergence of the internet the roles of teaching and learning started to change as previously the teacher was the knower and now the students have the opportunity to find and use the knowledge when they want and the way they want. This does not however mean that the teachers' role is less important, in this case, the teacher can help students to choose their learning pathways. In the last decades foreign language teaching scholars focused their interest on learner autonomy by giving different definitions, reasons for its spreading around the globe as well as the significance of learner autonomy in foreign language learning and teaching. As already stated in the introduction part, the most referred and influential definition of learner autonomy is stated by Holec (1981:3) "the ability to take charge of one's own learning". Alternatively, modified definitions can be seen in the literature where as it is stated by Little (1991:4) learner autonomy is defined as "a capacity- for detachment, critical reflection, decision- making and independent action". Further, Dickinson (1987:27) defines learner autonomy as "a mode of learning; one in which the individual is responsible for all decisions connected with her learning, and undertakes the implementation of these decisions". By the same token, Cotterall (1995:195) defines learner autonomy as "the extent to which learners demonstrate the ability to use a set of tactics for taking control of their learning". Learner autonomy is all about the learner and it's not about the learner studying alone. Teachers need to create appropriate learner opportunities for students as good students tend to be more autonomous and they take responsibility for their learning. In the same way, Hedge (2000: 410) describes it as "the ability of the learner to take responsibility for his or her own 
learning and to plan, organize, and monitor the learning process independently of the teacher".

Meanwhile, Benson (2003) states that "Autonomy is perhaps best described as a capacity ... because various kinds of abilities can be involved in control over learning. Researchers generally agree that the most important abilities are those that allow learners to plan their own learning activities, monitor their progress and evaluate their outcomes". (Benson, 2003: 290)

With regard to characteristics of autonomous learners, as cited by Wenden, 1998: 41, 42 there are seven main attributes that characterize these learners:

1. Autonomous learners have insights into their learning styles and strategies;

2. Take an active approach to the learning task at hand;

3. Are willing to take risks, i.e., to communicate in the target language at all costs;

4. Are good guessers;

5. Attend to form as well as to content, that is, place importance on accuracy as well as appropriacy;

6. Develop the target language into a separate reference system and are willing to revise and reject hypotheses and rules that do not apply; and

7. Have a tolerant and outgoing approach to the target language.

Taking into consideration the abovementioned attributes of an autonomous learner it is the teacher's role to reveal the students' knowledge that they have by assigning different in- class and out of classroom activities. Students need to take what we give them, digest it and make it for their own.

Given these points, Rubin and Thompson (1993) as cited by Karim Mattarima (2011) describe the characteristics of good language learners as follows:

1) Using the language at every available opportunity.

2) Practicing what they have just learnt as soon as possible.

3) Willing to try out different ways in order to get their message across.

4) Being able to overcoming their uncertainty and uneasiness.

5) Monitoring own speech as well as the speech of others.

6) Analysing, categorizing and synthesizing new language.

7) Systematic organizing program and goals.

8) Applying different learning methods.

9) Understanding errors in working or learning.

10) Starting conversation or be initiator of conversation.

With regards to this, one may ask what would be the most appropriate activities teachers need to assign to students if they are given the whole control over their learning. Subsequently, in order to promote autonomous learning opportunities to students Benson (2001: 111) suggests some teaching practices as supportive of autonomy by listing them as follows:

1) Resource-based approaches which emphasize learner's independent interaction with learning materials, 
2) Technology-based approaches which emphasize learner's independent interaction with educational technologies,

3) Learner-based approaches which emphasize the direct production of behavioural and psychological changes that enable learners to take control over their learning,

4) Classroom-based approaches which emphasize learner control over the planning and assessment of classroom learning,

5) Curriculum-based approaches which extend the idea of learner control to the curriculum, and

6) Teacher-based approaches which emphasize the role of the teacher and teacher education in the practice of fostering autonomy among learners.

\subsection{Significance of the study}

This study investigated how Basic English skills students at South East European University, Language Centre understand learner autonomy, their readiness for being autonomous learners and the possible dangers that may arise while implementing autonomous learning with the profile of such students. The results obtained from this study can shed light on avoiding the threats which were encountered while doing this study.

\subsection{Methodology}

This study was carried out at South East European University, Tetovo, the Republic of North Macedonia, in the academic year 2018/2019.

\subsection{Participants}

This study involved 53 participants, all students at South East European University, most of them in their first year of studies and from different fields of study. The students are aged 18-30 years old, and they are all non-native speakers of English.

\subsection{Results}

Shifting the responsibility for learning from teacher to learners in order to foster learner autonomy at the beginning of the study was problematic as students were dependant on teacher based learning and moving away from teacher dependence in the learning process required creating more space for learner participation and cooperation in order to enable students to take the risk of learning on their own. A lot of time was spent on giving explanations when assigning tasks to students as a result of the fact the students somehow found difficult to perform in front of their peers and being afraid of making mistakes. This is probably due to the fact that all students involved in this study are freshmen and do not know each other, therefore, such cases would not express their needs and concerns in front of their peers.

Another obstacle that was revealed during the study was when we went to the practical part of activities of group works where even within the group there were students who understood and those who didn't and when discussing as a group those who did not understand became aware that the problem lies in understanding the concept in the right way.

The tasks assigned for homework via Google Classroom were found as highly demanding and students mostly complained about the time limit set for doing the tasks. Although students benefited from the possibility of working independently there were some cases of 
weak students who were demotivated and when they discussed them with their peers in class, the areas they struggled with were revealed. There were also few cases of students who had problems with their internet connection at their houses and in the second homework they were passive and unwilling to work after their classes in spite of my support offered.

Time was another finding that is seen as a constraint for the fact that syllabi do not allow teachers to address the need for flexibility of the teaching and learning in order to promote autonomous learning as the material included the syllabus needs to be covered. This requires developing aspects of learner autonomy in the curriculum.

\subsection{Limitations and Recommendations for further research}

This study has the following limitations:

A more and in depth analysis should be carried out and with a larger number of students, with more time disposal so that the results are more reliable.

For the reason that Basic English Skills students were involved in this study, we could investigate how this method applies to ESP students.

\section{Conclusion}

According to the results of this study creating conditions to promote learner autonomy is a prerequisite in order to develop learner autonomy. The teacher has an unneglectable role in fostering learner autonomy with regards to seeking ways to help learners become more effective language learners. Teachers also need to well organize and manage the learning according to principles of autonomy and alert students to take responsibility for their own learning as they are given the leading role.

Learners need to be engaged in using the foreign language through their own efforts in order to develop foreign language proficiency and this can be done through enabling them to take responsibility. While doing this we need to be careful and clear enough with the instructions, namely, with weaker students because the study disclosed that they had difficulties in performing while engaged in different tasks.

A proper feedback for out-of-class activities helped learners to develop confidence when discussed in class and in further tasks got a feeling of security as showed by better marks in the second homework. 


\section{Berlin, Germany}

\section{References}

Benson, P. (2001). Teaching and researching autonomy in language learning. Essex: Pearson Education Ltd.

Benson, P. 2003. Learner autonomy in the classroom. In Nunan, D. (Ed.) Practical English Language Teaching. New York: McGraw Hill.

Cotterall, S. (1995). Readiness for autonomy: Investigating learner beliefs. System 23(2), 195-205.

Dickinson, L. (1987). Self-Instruction in language learning. Cambridge: Cambridge University Press.

Dickinson, L. (1987) Self-instruction in Language Learning. New Directions in Language Teaching. Cambridge Language Teaching Library. Cambridge University Press.

Hedge, T. (2000). Teaching and learning in the language classroom. Oxford: OUP

Holec, H., 1981: Autonomy and foreign language learning. Oxford: Pergamon. (First published 1979, Strasbourg: Council of Europe)

Karim Mattarima. (2011). Understanding students' learning strategies as an input context to design English classroom activities. International Journal of Psychological Studies. Vol.3, No. 2, December 2011, pp. 238-248.

Littlejohn, A. (1985) Learner choice in language study. ELT Journal, 39(4).

253-261.

Little, D. (1991). Learner autonomy : Definitions, issues and problems. Dublin: Authentik.

Wenden, A. 1998. Learner Strategies for Learner Autonomy. Great Britain: Prentice Hall.

Zhuang, J. (2010). The changing role of teachers in the development of learner autonomyBased on a survey of "English dorm activity". Journal of Language Teaching and Research 1(5), 591-595. doi:10.4304/ jltr.1.5.591-595 